\title{
Cabaré da SANTA
}

http://dx.doi.org/10.11606/issn.2175-3180.v12i23p213-271

Reinaldo Maia ${ }^{\mathrm{I}}$

Jorge Louraço Figueira II

\section{APRESENTAÇÃO DO TEXTO DRAMATÚRGICO CABARÉ DA SANTA}

Helder Mariani ${ }^{I I I}$

Escrito por dois dramaturgos separados pelo Atlântico, o Cabaré da Santa, que antes deveria se chamar Cabaré da Liberdade, traz na sua narrativa uma vontade comum que os reuniu - celebrar, nos idos de 2008, os duzentos anos da chegada da família real portuguesa em terras brasileiras, primeiramente na cidade de Salvador, para depois se instalar com sua corte no Rio de Janeiro. Pronto! Eis um bom motivo para celebrar no teatro esse fato significativo, com atores brasileiros e portugueses, as histórias e fantasias que reúnem esses dois países.

Assim, a partir desse mote inicial de uma celebração artística e crítica desse fato histórico, dois grupos teatrais criaram um projeto em parceria: o Folias, de São Paulo, que trouxe como dramaturgo um de seus fundadores, Reinaldo Maia; e o Teatrão, de Coimbra, que trouxe Jorge Louraço Figueira como seu dramaturgo. A parceria deu certo e, juntos ou separados, a escrita dessa dramaturgia fluiu e surgiu para ser oferecida aos atores dos dois grupos teatrais. Foram duas montagens, uma em São Paulo e outra em Coimbra; ambas encenadas pelo mesmo diretor brasileiro, Dagoberto Feliz, também um dos fundadores do Folias, ainda no ano de 2008.

Uma comédia divertida dividida em três longas cenas - que nas

\footnotetext{
I Dramaturgo.

II Universidade de Coimbra, Coimbra, Portugal.

III Pontifícia Universidade Católica de São Paulo.
} 
duas encenações se transformaram em vários quadros - com críticas claras e abertas, como nos antigos teatros de Revista, com seus números artísticos rápidos e seus discursos diretos para a plateia, traziam com bom humor as mazelas sociais de seu tempo. As duas montagens do Cabaré da Santa ilustraram as diferenças e semelhanças entre esses dois povos e seus humores. Também no texto dramatúrgico é possível perceber essas diferenças nas escritas, ora mais abrasileiradas, ora mais aportuguesadas, mas sempre com a mesma crítica feroz, que revira o passado para condenar despudoradamente as injustiças do presente.

A primeira montagem foi realizada no Brasil, no Galpão do Folias, onde era comum nos ensaios a presença de Reinaldo Maia sentado na plateia, divertindo-se muito. Maia faleceu no ano seguinte, em 2009. De lá para cá, companheiro Maia, muita coisa se transformou aqui em terras brasileiras, coisas que fariam você ficar terrivelmente irritado, e escrever muitos outros Cabarés! Mas aquele que você escreveu com o Jorge continua sendo muito bem-vindo nestes tempos atuais... O riso e o deboche continuam sendo formas eficazes, e talvez únicas, de se enfrentar um poder autoritário e corrupto.

\section{PERSONAGENS}

\section{CABARÉ dA SANTA - 0 TEXTO}

\section{MENDES}

MARIA ISABEL, A MARIQUINHAS

BENTO TEIXEIRA

JUSSARA

RAFAELA

TRANCOSO, ALIÁS EL-REY D. JOÃO

LEOPOLDINA

SANTA CECÍLIA

\section{CENA I}

Um velho cabaré decadente. Ouvem-se os risos e cantorias das meninas lá dentro. As luzes apagam subitamente, com um estoiro. Entra Mendes com uma lanterna. Bailarinas apressadas colocam velas acesas nas mesas.

MENDES - (Sempre sorrindo.) Bem-vindos ao Cabaré da Santa, para a estreia do novo show, um grande sucesso, dentro e fora! Preparado especialmente para as comemorações que se avizinham, hoje assistirão a uma série de 
fantasias e deturpações, mais ou menos originais, do que se passa no seio dos homens e das mulheres... através do tempo e do espaço! E o que chamam de estória... Um contar sem explicar, um saltar de um acontecimento a outro, sem parar-se para a interpretação das partes - e, menos ainda, do todo. Assim será lembrada essa data memorável, que também faz parte da génese deste cabaré... (A luz volta.) Por isso, não percam tempo cavucando, fazendo a autópsia do mostrado. $O$ que verão são belas imagens, lembranças de vivências pessoais preservadas em sua primorosa inutilidade afetiva! Devaneios, para evocar os tempos idos! Nessa estória que vão ouvir...

ISABEL - (Bêbeda.) Mendes, ninguém veio até aqui para escutar sua filosofia de quinta. Isso tudo são só arremedos para disfarçar a tua decadência, homem!

MENDES - Mas se faz necessária uma introdução... Ó Mariquinhas... nada como uma boa estória para começar...

ISABEL - Não e não! Eu quero a história com agá... Que nervos! Estou cansada de dizer. Aqui revelamos a verdade, não fantasias! A versão verdadeira da história, a que nos tem sido ocultada, desde o início dos tempos, no que ela tem para nos contar sobre hoje! Rumo à libertação cultural das mulheres!

MENDES - (Entre dentes.) Mariquinhas! Enlouqueceu? Isto é um cabaré! As mulheres fazem... (Corrige. Mais alto.) Fazem números de variedades! Por isso eu estou dizendo...

ISABEL - Quer melhor show de variedades que a história com agá? Não e não! Tem paixão, tem acção, aventura... e tem... sexo! A História em grande, com maiúsculas e ponto de exclamação! O facto, senhoras... (Pausa. Olha em volta.) se não temos senhoras esta noite no Cabaré peço muita desculpa... o facto, camaradas, é que a história só existe quando é contada!!... É como se existisse um encontro secreto marcado entre as gerações anteriores e a actual. Por isso tanto faz se Cabral nasceu em 1500 ou não, ele nasce e morre todos os dias aqui, quando abrimos as portas para vossas excelências se servirem de nós, e beberem dos nossos copos e 
comerem dos nossos corpos... Se está tudo misturado é porque...

MENDES - ...Aqui é o Ó da História, o fundo do poço... E essa verdade histórica vem é do fundo do copo mesmo! (Tira-lhe a bebida e oferece a algum espectador.) Você prometeu que ia deixar de beber quando houvesse clientes!

ISABEL - Cale-se! Você não leu os manuscritos do mar morto? A mulher é a única verdade histórica, e seu ventre é uma taça milagrosa! Por isso nós estamos aqui, e eu ergo essa taça a Santa Cecília, nossa padroeira, ela que continuou cantando enquanto o carrasco a decepava com golpes de machado... É isso que eu estou dizendo! E você não vai me calar nem que desfira seus golpes mais poderosos. Que você não tem mais, aliás. E eu vou provar isso, aqui e agora!... Está toda a gente servida e de copo na mão, não? Vamos começar! Deixe de bobagens, Mendes, e abra espaço para as meninas. É que temos de brindar! À nossa!

MENDES - As meninas não! Tem alterações a fazer no roteiro! Eles podem chegar a qualquer momento! Eu escrevi versos novos, mais alegres.

ISABEL - Eles?

MENDES - Sim, eles.

ISABEL - Mas eles, quem?

MENDES - Vamos esperar por eles. O número não está pronto! Primeiro eu tenho de explicar ao público presente...

ISABEL - Mas quem são eles?

Mendes - Você sabe. (Entre-dentes.) Os investidores.

ISABEL - (Caindo a ficha.) Ah!... Você convidou eles hoje?

MENDES - Sim. 
ISABEL - De Portugal! Chegam hoje! E eu assim!

Continuam a discutir, enquanto o canto das meninas se sobrepõe às vozes deles.

CORO DAS MEninas (Cantam "Depois do Leilão".)

A casa da Mariquinhas

Já nada tem que a destaque

As discretas tabuínhas

São dum velho bricabraque

Em prol da urbanização

E d'outras leis citadinas

Inventaram-se as ruínas,

Impôs-se a demolição.

Lá foram no turbilhão

Muitas relíquias velhinhas,

Porém, as fúrias daninhas

Das inovações em suma,

Por "salvação", ficou uma:

"A casa da Mariquinhas"

No célebre primeiro andar

Que a Mariquinhas deixou

Nem uma placa ficou

Do seu nome a assinalar.

Abertas de par em par

As janelas, são mesquinhas,

Até as próprias vizinhas

Confessam com amargor

Que falavam mais de amor

As discretas tabuínhas.

(Um foco ilumina MENDES.)

MENDES - Eu escrevi versos novos! (Tentando salvar a situação, para o público:) Esta casa, tão tradicional, foi fundada por Conde Coligny, antigo cabaretier francês, obrigado a fugir para o Brasil, que ele conhecia como o "Éden dos 
Especuladores Cosmopolitas". Isto depois passou por um mau bocado, chegou a ser um galpão de teatro, mas felizmente isso acabou... Hoje é apenas um museu de art nouveau... Foi tombado quando se descobriu que aqui era o cabaré original de monsieur le Comte de Coligny... Hoje dirigido por moi-même e por madame Mariquinhas... Mas o principal...

\section{ISABEL (Canta.)}

Mas outra fisionomia

Lhe deram; não tem guitarras,

Lá dentro não há cigarras

Cantando a sua alegria.

À porta por ironia,

Há um porteiro, um basbaque,

A olhar por um "Cadillac"

da pessoa que lá mora...

Das coisas velhas d'outrora

Já nada tem que a destaque.

MENDES - O principal valor desta casa vem do facto de, antes disso, aqui terem sido planeadas as primeiras incursões em busca do Eldorado, nesse solo, que ainda se pode tocar descendo por um túnel que parte da cave... não fora a humidade! Eu pessoalmente não desço lá por causa da asma. Mas ninguém dá nada por isto, não é mesmo? Está muito caído e precisado de investimento. Porém, o interesse turístico é óbvio. Por baixo destas tábuas corre um fio de água onde em 1555 foi encontrada uma imagem da Santa milagrosa apontando com o olhar na direcção de Eldorado, e por isso os jesuítas estenderam aqui a primeira rede e disseram a primeira missa em tupi. Dizem que esse fio vai, de lençol em lençol de água, através de um labirinto de galerias subterrâneas, dar ao verdadeiro lago Eldorado. Não sabemos se é verdade, porque nunca uma alma voltou dessas expedições... Mas se conseguirmos atrair o investimento, vamos conseguir sair desta miséria...

CORO DAS MENINAS

A Ti'Ana, a capelista,

Triste, queixa-se das vendas,

Já não tem saída as rendas 
Nem os xailes à fadista.

O Perdigão penhorista,

Um velho de côco e fraque

Diz que tudo esteve a saque,

Que só 'spartilhos e ligas

Porque eram coisas antigas

São dum velho bricabraque

MENDES - Toda essa agitação de hoje não é sem motivo. Em honra dos velhos tempos e das tradições de outrora, além do show temos ainda programado um pequeno concurso para entreter os nossos investidores esta noite. Vamos eleger, entre as bailarinas, a rainha do cabaret, que ganhará o direito a ser sorteada pela comitiva de fraternos lusitanos que está chegando para o estudo e comprovação do mito de Eldorado. A felizarda levará depois o português para uma clássica garçonnière, ao melhor estilo carioca. É o pacote completo do amor tropical. (Canta.)

Minha terra tem palmeiras

Onde canta o sabiá

Situada no mundo da lua

A $38^{\circ}$ graus à sombra.

Minha terra tem mulheres

Vida feliz e nômade, sem lar

Uma alegre feição de eterno piquenique.

Aqui

Vive-se feliz, sem lei, sem rei nem rock

Como única riqueza uma flecha e um bodoque.

Aqui todos mandam e ninguém obedece.

Cada um cava por si e Deus por todos.

O bocado não é para quem o faz,

É para quem o come.

Quem tem vergonha morre de fome.

O futuro a Deus pertence,

No Eldorado sonhado do Homem.

ISABEL - Mas Mendes!... Que história é essa?!

MENDES - Mulher ignara! É a nossa história! 
ISABEL - Isso até parece nome de furacão! Eldorado?...

MENDES - Só de ouvir fica logo sabendo o que é! Toda a gente sabe o que é, aliás! Só você não entende nada depois fica me criticando... Ainda fica falando de história com agá... Pergunta às senhoras do público, se não sabes!

ISABEL - Não tem senhoras no... Alguém do público sabe? Meninas? É uma grife?...

MENDES - Vamos voltar ao número. E um, e dois, e...

ISABEL - Na cave?

JUSSARA - Isso tudo me parece demasiado desconexo. Eu acho que você está se referindo ao significado oculto -

MENDES - (Interrompendo.) Que nada! Desconexo é o mundo em que nós vivemos! E um, e -

JUSSARA - Eu contesto! Se você observar bem, há sempre, ao longo dos tempos, uma razão oculta nos desígnios da humanidade, e a nós cabe saber encontrá-la nas confluências da história, quando -

MENDES - (Interrompendo.) Exactamente! E nós precisamos aproveitar este momento... da confluência... entre nós e os portugueses...

JUSSARA - Mas o Eldorado não é real, é um mito, ele apenas simboliza nossa busca -

MENDES - E com as comemorações oficiais, estamos buscando um bom subsídio. É dessa confluência que estou falando. Vamos ver no final se tudo isto não tem uma ordem! Mas por enquanto, a desordem. Isso é o que nós temos para vender aqui no Cabaré. Pois quem quer ser todo ordenado, quando pode ter uma pitada de desordem também?! (canta.)

Minha terra tem palmeiras 
Minha terra tem mulheres

AS MENINAS (cantam.)

É numa rua bizarra

A casa da Mariquinhas

Tem na sala uma guitarra

E janelas com tabuinhas

ISABEL E MENDES (cantam.)

Quem tem vergonha morre de fome.

O futuro a Deus pertence,

No Eldorado sonhado do Homem.

(Toca uma sineta.)

Mendes - São eles! Viva Portugal! Viva! (Entra Bento Teixeira. Desilusão geral.) Mas é você de novo, Bento? Eu ainda não lhe posso pagar o dinheiro que me emprestou... e hoje você não pode ser visto aqui! Estamos nos preparando para receber uma comitiva de Portugal que traz representantes da coroa, da nobreza e do clero!

BENTO - Pois precisamente! Mal soube vim a correr.

ISABEL - Do povo não vem ninguém?

MENDES - Lá não tem povo: é um país desenvolvido.

JUSSARA - O povo veio para cá faz tempo, clientela ruim...

BENTO - Eu não sou do povo, Jussara.

MENDES - Bento, escute, a comitiva tem a bênção papal! Dizem até que vem um representante oficial do Vaticano, incógnito...

BENTO - Bem sei. Estou à espera disso há mais de quinhentos anos!!

JUSSARA - Comitiva de nobres e seminaristas... Mais cabritos para o 
desmame. Vai dar trabalho prá noite inteira!!

MENDES - Nada disso, Jussara, nada disso! É uma visita didática às terras de Vera Cruz, e a excursão ao verdadeiro e secreto lugar de Eldorado! Tudo para convencer El-Rey que aqui se pode muito bem montar o Sexto Império e fugir das estrepolias desses Napoleões de mão no bolso. E isto é oficial!

ISABEL - Saltámos o Quinto Império?

MENDES - Não me atrapalhes, Mariquinhas, nunca foste boa de contas. É o verdadeiro império, o de Eldorado, seis estrelas! Vêm para avaliar as oportunidades de investimento. Valem o peso deles em ouro! Eu não posso correr riscos, compreende? Por isso estamos ensaiando algumas alterações aos... números. Estou cansado de dizer isso.

JUSSARA - Ah, eu pensava que as cantorias novas eram apenas serviço personalizado. Português tem cada tara que eu pensei...

BENTO - Eu não sou um português qualquer, Jussara...

ISABEL - Tem cada tara marada que eu bem sei o que nos custa a fazer!

JUSSARA Ai, português, portuguesinho, pra que foste sair do ninho? Comer o pão, beber o vinho, Com esta companhia... antes sozinho!

BENTO - Eu não admito, Jussara! O meu nome é Bento Teixeira, descendente de uma linhagem dourada, e sou uma vítima! Posso provar com o meu corpo! (Vai para baixar as calças. É impedido por Jussara.)

JUSSARA - Pronto, Bento, eu sei, eu já vi!

ISABEL - Mas então... É isso... vamos mostrar a eles a única verdade histórica, só que na forma de Eldorado... Vou já preparar tudo. (Sai.) 
MENDES - Por favor, Bento, vá embora. Aguardamos os mais altos representantes da gente da santa igreja.

BENTO - Mas por isso mesmo - deve vir algum responsável pela inquisição. $\mathrm{Eu}$ vou finalmente esclarecer com eles o que se passou, repor a verdade dos factos, e reclamar a minha indemnização histórica. Quero minha reputação limpa e minha conta bancária recheada, se não conto tudo o que sei sobre esses portugueses sanguessugas, o ouro do Brasil e de onde vem esse ADN corrompido!

MENDES - Mas se és visto aqui... um cristão-novo no meio dos seminaristas... eu posso até arranjar problemas com o cardeal.

BENTO - Você sabe com quem está falando? Eu sou o melhor cliente desta casa...

MENDES - Sei muito bem! Por sua causa, só não perdi a licença porque ela já estava caducada. É que, na hora da verdade, não dá para disfarçar... você é circuncidado!

BENTO - Pergunto de novo. Você sabe com quem está falando, Mendes?

MENDES - Mas foi um trabalho bem feito, lá isso foi. E tem vantagens, sem dúvida...

BENTO - (Grita.) VOCÊ SABE COM QUEM ESTÁ FALANDO? Foi com minha filha que se iniciou a actual dinastia monárquica, você sabe disso, não sabe? A crise de sucessão, a guerra e a paz... Para tudo eu emprestei o meu ouro, e paga que tive foi a fogueira! Dei o ventre de minha filha! Eu quero repor a verdade!

MENDES - Mas se eles ainda não lhe perdoaram por isso mesmo, porquê insistir?

Silêncio. BENTO canta "Verdadeira Embolada" de Edu Lobo e Chico Buarque.

A verdade que se preza

É fiel que nem um cão 
A de César é de César

A de Cristo é do Cristão

A mentira anda na feira

Vive armando confusão

Cheia de perfume, rebolando na ladeira

De mão em mão

A mentira e a verdade

São as donas da razão

Brigam na maternidade

Quando chega Salomão

A razão pela metade

Vai cortar com seu facão

Vendo que a mentira chora e pede piedade

Dá-lhe razão

$\mathrm{Na}$ realidade

Pouca verdade

Tem no cordel da história

No meio da linha

Quem escrevinha

Muda o que lhe convém

E não admira

Tanta mentira

Na estação da glória

Claro que a verdade

Paga a passagem

E a outra pega o trem

A mentira, me acredite

Com a verdade vai casar

Se disfarça de palpite

Pra verdade enfeitiçar

Todo mundo quer convite

A capela vai rachar

Pra ver a verdade se mordendo de apetite

Ao pé do altar

$\mathrm{Na}$ verdade cresce a ira

A mentira é só desdém

A verdade faz a mira 
A mentira diz amém

A verdade quando atira

O cartucho vai e vem

A verdade é que no bucho

De toda mentira

Verdade tem.

MENDES - Por isso mesmo! Pode ser que essa história de Sexto Império, de Eldorado, de Lusofonia, seja verdade.

JUSSARA - Ainda se fosse lusofolias...

ISABEL - (Entrando.) A única verdade que vejo na mentira é que isto é um bordel e não uma academia! Embora tenha caloiros, muitos doutores, aulas, borlas, e capelos.

BENTO - Não brinque com os meus sentimentos, Mendes!

MENDES - Calma, Bento, calma. O melhor, Bento, é o seguinte: nós estamos a meio de uma apresentação. Você vai com Jussara se esconder, e eu tento sacar a verdade. Aí você entra. Para tentar repô-la. Jussara, minha filha, leva seu Bento para tomar um refresco. (Saem. Mendes prepara-se para dirigir a palavra à plateia, quando Isabel interrompe.)

ISABEL - Fui verificar e de meninas só temos a Jussara. O resto é macho mesmo. Acha que eles vão gostar? Não é o verdadeiro Eldorado...

MENDES - Ah, você tem mesmo vistas curtas. Isso não tem a mínima importância.

ISABEL - O quê?

MENDES - Esqueça o sexo deles e delas. Sexo tem muita concorrência, precisamos diversificar.

ISABEL - E isto vai virar o quê? Nós não sabemos fazer mais nada! Foi você que dispensou as meninas e manteve os travecas apenas. 
MENDES - Eles levam mais barato e nós estamos sem dinheiro, Isabel. Por isso eu insisto, temos de mudar o branding.

ISABEL - Que mal tem este brandy?

MENDES - Branding! Temos de mudar a imagem de marca.

ISABEL - Ah...

MENDES - Ninguém mais quer vir ao Cabaré, desde que esse sindicato se organizou... não dá para pagar segurança social, décimo terceiro, subsídio de férias... Vão levar na passarinha!! Os credores batem à porta, e nós temos que arranjar dinheiro. O Fundo das Mulheres Internacionais - o FMI dos cabarés está a nos caçar. Já espalhei pela cidade inteira que a comitiva de portugueses, com a bênção papal, estará aqui. Espero criar alguma clientela com isso. Afinal, vamos ser o centro de atracção da comitiva oficial. Mas se gasto tudo no salário das meninas...

ISABEL - O centro da atração internacional? Isso é pecado e nojento, Mendes. Enganar assim os pobres portugueses...

MENDES - Depois de experimentar, vão gostar. E ademais, sexo pelo sexo não dá - é preciso que tenha sexo pensando na história, tem de pensar que você é um rei ou uma rainha, que está comendo uma nação, ou a bolsa de Nova Iorque, ou a história do Brasil e de Portugal. Que interessa o cu, a cona ou o caralho? Interessa o que eles significam!! Sexo cultural, tá ligada? Tem turismo cultural, não tem? E tem turismo sexual também, não é certo? Nós vendemos sexo cultural.

ISABEL - O Ó da história... o cálice da verdade... o tronco da sabedoria... Tal como eu sonhara... Como você pensou nisso?

MENDES - Eu conheci essa Rafaela, uma personagem, você vai ver. Ela me deu muitas ideias de negócio, algumas utópicas, outras nem tanto.

ISABEL - Uma personagem?... Não é de verdade? 
MENDES - Você acha que estou brincando? Foi jeito de falar, claro que é de verdade. Se chama O Tupi, a agência de viagens.

ISABEL - Mas qual é o seu plano, afinal?

MENDES - Rever o perfil desse Cabaré. Esquecer o teatro. O nosso negócio tem de ser números de variedades, numa mão, e liberdade de costumes, na outra. Esse é que é o nosso Eldorado. A arte e a sedução de mãos dadas, entende? Os portugueses vão querer investir, é claro. Foi por isso que eles mandaram Cabral em 1500, que o Marquês de Pombal enviou o próprio irmão em 1751, e que o Rei em pessoa veio para cá em 1808 . O século vinte deles é apenas um episódio de beatice numa longa vida de luxúria... Mas são loucos por sexo cultural...Eles precisam é de ser descobertos.

JUSSARA - Tem uma dona Rafaela no rádio de onda curta.

MENDES - Olha eles aí.

\section{CENA II}

No outro lado do Atlântico.

RAFAELA - Senhoras e senhores, estamos aqui hoje para iniciar a viagem ao verdadeiro Eldorado. Eu serei vossa modesta guia nesta aventura sem par. Um novo mundo se descortinará perante vós, dando a oportunidade de descobrir o vosso "eu" mais primitivo, mais próximo do que foi e viveu Adão antes de ser expulso do Paraíso. Terão a oportunidade de conhecer o Éden terreno, longe de espanhóis, franceses, ingleses e próximos da natureza imaculada. Logo na chegada sentirão o olor tão bom e suave das flores e árvores da terra, a coisa mais doce do mundo. O povo é amoroso, sem cobiça, e conversável para qualquer coisa... afirmo que melhor gente não há: eles amam a seus próximos como a si mesmos e têm uma fala a mais harmoniosa do mundo, mansa e sempre com alegria. Adoecem muito pouco e os que adoecem logo saram. Os montes parecem formosos jardins e certamente eu nunca vi tapeçaria de Flandres tão formosa, nos quais andam animais de muitas diversas maneiras, dos quais Plínio nem escreveu nem soube. Certamente bem resplandece a grandeza, formosura e saber do Criador em tantas, tão diversas e formosas criaturas. E tudo isso 
financiado em curtíssimos 36 meses... (Canta "Canção do Exílio" de Gonçalves Dias.)

Minha terra tem palmeiras

Onde canta o sabiá:

As aves que aqui gorjeiam

Não gorjeiam como lá.

Nosso céu tem mais estrelas,

Nossas várzeas tem mais flores,

Nossos bosques tem mais vida,

Nossa vida mais amores.

Em cismar, sozinho, à noite,

Mais prazer encontro eu lá;

Minha terra tem palmeiras,

Onde canta o sabiá.

Minha terra tem primores,

Que tais não encontro eu cá;

Em cismar - sozinho, à noite -

Mais prazer encontro eu lá;

Minha terra tem palmeiras

Onde canta o sabiá.

Não permita Deus que eu morra;

Sem que eu volte para lá;

Sem que desfrute os primores

Que não encontro por cá;

Sem qu' inda aviste as palmeiras,

Onde canta o sabiá.

SANTA - Senhora Rafaela...

RAFAELA - Pois não, quer fazer uma reserva?

SANTA - Uma intimação. Mas não se assuste. A senhora obteve benção papal e subsídio estatal para essa sua aventura ao Novo Mundo, não foi? Pois bem, está tudo nos conformes com o seu processo, a papelada e tal... 
Mas os serviços de sua majestade gostariam de lhe pedir um favor... a senhora terá que levar como conselheiro espiritual o Padre Francisco da Costa, prior de Trancoso...

RAFAELA - O prior de Trancoso?

SANTA - Padre Francisco da Costa. Não ouviu o que eu disse?

RAFAELA - Mas ele foi condenado! Eu mesmo vendi lugares na primeira fila para assistir ao esquartejamento! Onde está o anúncio? (Procura.) Degredado das ordens e arrastado pelas ruas públicas, pelo rabo dos cavalos, era a sentença. Chorei nesse dia... Achei! (Lê.) ...Sendo acusado de ter dormido com vinte e nove afilhadas e tendo delas noventa e sete filhas e trinta e sete filhos...

SANTA - (Interrompendo.) Fale baixo...

RAFAELA - (Lê.) ...de nove comadres trinta e oito filhos e dezoito filhas; de sete amas teve vinte e nove filhos e cinco filhas; de duas escravas teve vinte e um filhos e sete filhas...

SANTA - (Interrompendo.) Sim, nós sabemos... Mas temos de ver as coisas pelo outro lado também...

RAFAELA - (Lê.) ...dormiu com uma tia, chamada Ana da Cunha, de quem teve três filhas, da própria mãe teve dois filhos, num total de duzentos e noventa e nove, sendo duzentos e catorze do sexo feminino e oitenta e cinco do sexo masculino, tendo concebido em cinquenta e três mulheres... Por tudo isso, será esquartejado o seu corpo e postos os quartos, cabeça e mãos em diferentes distritos, pelo crime que foi argüido e que ele mesmo não contrariou. Está aqui a prova. Foi esquartejado! Como pode ele ir para o Brasil? Em caixas separadas? (Pausa.) Você é a morte?

SANTA - Você não acha que vai reconhecer a morte, quando ela vier?

RAFAELA - Vem vestida de preto, a pedir passagem para gente morta... Pensei que já queria os meus serviços. Eu viajo para o Novo Mundo, não 
para o Além Mundo, viu?

SANTA - O Trancoso está vivo!

RAfaela - Ele ressuscitou? (Pausa.) Você é o Messias!

SANTA - Eu não sou o Messias coisa nenhuma, sou - (Muda de assunto.) $\mathrm{O}$ Trancoso não chegou a morrer! El-Rey D. João perdoou-lhe a morte. O verdadeiro prior foi salvo, em nome do interesse nacional. $\mathrm{O}$ senhor não está contra o interesse nacional, está?

RAFAELA - Não, não, tudo pela nação!... Ele está vivo... Mas é muita fruta! Há mulheres a bordo!... Só com cinto de castidade! E quem usa é ele!

SANTA - Quem vos dera receber a semente de... (Muda de assunto.) El-Rey quer que o Prior catequize os indígenas, e que ajude a povoar aquelas terras tão despovoadas... de bebezinhos fiéis à coroa. Está tudo aqui.

RAFAELA - E isto tem o selo régio?

SANTA - Você está duvidando de minha prova documental, exarada dos tribunais e da corte, contra um folheto de agência de viagens? Devo lembrar-lhe que guia turístico não é historiador? A verdade está aqui.

A origem da trancada

Foi nas terras de Viseu,

Onde o Abade de Trancoso

Perdeu conta às que deu.

A lenda está comprovada

$\mathrm{P}^{\prime}$ los filhos que cometeu.

Cada trancada que dava,

Nascia um cidadão.

E o Prior foi nomeado

Abade de cobrição.

Pode bem ser que tenhas 
Um Trancoso no coração.

Foder uma ou duas moças

É pecado capital.

Trancadas em mais que muitas

É virtude nacional.

Dizem que Gengis Khan

Teve mais filhos que Adão.

Isso nem se compara

ao abade fodilhão.

Nunca pecou por deixar

A semente cair no chão.

Khan povoar a Mongólia

É pouco mais que adultério.

O Abade de Trancoso,

Esse, fez o quinto império!

\section{Entram Trancoso e Leopoldina.}

LEOPOLDINA - (Entregando um cinto de castidade a RAFAELA.) Eu não vou tomar conta desse abade fodilhão!

RAFAELA - Mas querida, já te disse, tu só tens de alternar! Dás duas de treta, uns pézinhos de dança, e fá-los pagar a champanhota! O resto... é contigo.

LEOPOLDINA - Mas chegando lá, estou de férias! Também sou gente.

RAFAELA - Olha que este é peixe graúdo... (Para Trancoso.) Desculpe o mau jeito...

TRANCOSO - Chega mais perto, para te ver melhor...

RAFAELA - Pai!... 
TRANCOSO - Filha!?

RAFAELA - Sim, não te lembras?...

TRANCOSO - Assim de repente, não. Mas eu só fazia, não os criava.

RAFAELA - Minha mãe sempre dizia: és filha de uma trancada!

TRANCOSO - (Tentando acertar o nome.) Maria?...

RAFAELA - (Exasperada.) Rafaela! Mas eu também sou da Costa...

TRANCOSO - Que pena... És bem gostosa. (Aparte.) Tenho de ir embora deste país! (Indica LEOPOLDINA.) Fico com esta outra para camareira, então.

RAFAELA Tem filho que não tem pai,

Sofre por ser enjeitado.

Tem outros como eu

Sofre com pai afamado.

Que vale ser da prole

De um pai tão abonado?

LEOPOLD. Come a própria filha

Se ela não toma cuidado.

Chegam mais passageiros e começa o embarque, a viagem e tudo. MENDEs, da América do Sul, espreita por uns binóculos, vendo a cena toda.

RAFAELA - Embarquem, embarquem, não temos tempo a perder. Queridos aventureiros pós-modernos, hoje inicia a nossa viagem por águas idílicas nem tão virgens, mas sempre calientes, rumo ao não tão novo continente na busca de novos negócios e prazeres. Hoje se inicia o nosso tour Globalizante. Tragam em suas malas todas as bugigangas que aqui, em nosso velho e aborrecido país, já não conseguimos passar adiante. Passados quinhentos anos já é hora de refazermos esse caminho, de fugirmos dos nossos males, desta carcomida Europa, de refundarmos uma tradição. Não esqueçam, nestes tempos de comportamentos politicamente 
corretos, há que se mostrar consideração com nossos irmãos emergentes. Compreensão não é comiseração. Afinal, não se tem prazer nem lucro sendo só bom irmão. Cantemos, essa nova canção:

América, América,

Como aves de arribação

Estamos chegando

Trazendo a todos novas ilusões.

América, América,

Sonhos e sonhos

Esperanças mil

De entrar no restrito

Círculo rico

Da congregação do norte.

América, América,

Gigante adormecido

Do sol de todos os dias

Do mar azul cor de anil

Da rede no coqueiro

Da mulata lisonjeira

Das mudas de bananeiras.

Cá estamos nós

A caminho do adorado

Eldorado tropical.

RAFAELA - (continua) O conforto de um transatlântico singrando as verdes águas do Atlântico. Isto é o progresso. Passado quinhentos anos, seguimos a mesma rota daqueles que em naus primitivas, deixaram para trás família e tradição, para descobrir um Novo Mundo. Refazemos a trajetória para contar uma nova e mesma história. Os tempos são outros, outros são os negócios. "Negócio \& Prazer, o lucro com satisfação". Assim muita felação, para expandir o mercado e garantir a dominação.

Os passageiros desembarcam com suas bagagens.

CORO Sede bem-vindos

Caros irmãos 
Nesta terra da promissão

Deixem suas culpas

Lá trás.

Venham junto a nós

Festejar!

O Eldorado os espera

Para ser descoberto

E gozado.

Novos negócios se concretizarão

Sem culpa e desculpas

Pra se fazer.

Abaixem as calças

Vamos brincar

De papi e mami

Sem cansar.

Nos conhecer

Sem ofender.

O Eldorado os espera

Para ser descoberto

E gozado.

No Cabaré da Santa.

MENDES - Sejam bem vindos! Sintam-se em casa! Aqui nada vos faltará, bebidas para relaxar, comidas para saborear, mulheres para acompanhar!... e, para não dizer que não trabalhamos, nos intervalos teremos... negócios! Entre uma caipirinha e uma nativa tudo é permitido desde que tenham os euros para gastar, não é?... Se quiserem privilégios já sabem, uma comissão terão que pagar!... Para isso basta ter esse dinheiro de brincar, essas fichinhas, como no monopólio! Estão à venda na entrada, podem pegar, façam favor. Afinal, essa é uma ilustre tradição trazida do velho continente, em tempos menos emergentes, pelos nossos queridos colonizadores e que aqui recordamos com saudade. Ah, as minhas pálpebras lutam para não deixar o choro envergonhar meus olhos nessa hora de recordação. Façamos o tempo voltar para trás, aqui, hoje, agora!! O Eldorado em suas mãos, vendido em módicas prestações, apenas com ínfimo lucro, certo, a perder de vista, destinado a investimento público nacional! Acomodem-se, o 
show já começou!

JUSSARA $e$ TRANCOSO, encantados um com o outro.

JUSSARA - Venha ver a paisagem. Olha que coisa mais bela, mais selvagem... mais... ulálá, que potência...

TRANCOSO - Querida irmã, não devemos negar a outrem aquilo que deus nos deu com tanta generosidade. Vivemos uma época de expansão da nossa lusofonia...

JUSSARA - Nem me diga... não sou eu que vou dizer que não. Mas antes, querido irmão, quais são suas reais intenções?

TRANCOSO - Ampliar os horizontes, estabelecer novas relações...

JUSSARA - Você vai me levar para a Europa?!... Me leve... olhe o que eu sei fazer!

TRANCOSO - Ah!... introduzir nos nativos os novos conceitos da modernização!

JUSSARA - Não sei porque não me parece estranha essa sua cantilena.

TRANCOSO - Provavelmente já cá chegou a fama das trancadas que o Trancoso dá... e você não hesita. Cuidado minha querida... não tem um lugar mais reservado?

JUSSARA - Creio mesmo já ter pego nesta vela benta, mesmo que em modelo nacional.

TRANCOSO - Esta vela está derretendo nas suas mãos, querida... Quase me queima... Mas a cera é produto de Portugal, vinda directamente de Braga, da Roma portuguesa...

JUSSARA - Não, não é isso não... é a forma dela... mas está qualquer coisa aqui a mais... a outra é mais escorreita... 
TRANCOSO - Mau! Não confunda a grife com a falsificação!!

JUSSARA - Esta é como se tivesse passado à pressa pela circuncisão!

TRANCOSO - Então só pode ter sido coisa desse meu meio irmão! Fale baixo!! Você o conhece?

JUSSARA - Bento Teixeira? Como a palma da minha mão!

TRANCOSO - Esse tal Bento Teixeira, que por essas terras andou a disseminar a libertinagem religiosa, é um criminoso da fé, da esperança e da castidade. Quero lhe alertar, indiazinha do Brasil, não confie nas cópias nacionais. Ouvi dizer que a pirataria tem causado malefícios pecaminosos à globalização, e você não quer isso, quer? Prefira sempre o produto original. Vou-lhe mostrar a qualidade certificada da vela.

JUSSARA - Ah, e onde poderei encontrar essa originalidade?...

TRANCOSO - Bom, se você tiver uma gazua... eu posso abrir este cinto...

MENDES e RAFAELA, encantados um com o outro.

MENDES - Então, Rafaela, está gostando da recepção?

RAFAELA - Não tenho muito do que reclamar. Talvez...

MENDES - Talvez... o quê?

RAFAELA - Talvez o que me tenha deixado um pouquinho descontente é que a gente não esquece a primeira vez. Que saudades das excursões de 1500 , de 1751 , de 1808 !

MENDES - Lá isso é verdade, a primeira vez a gente nunca esquece, mesmo que tudo façamos para que as coisas mantenham seu sabor original.

RAFAELA - O velho e bom selvagem! Hoje, esse mito só conservou da sua 
antiga imagem a violência natural. Não me esqueço da festa da chegada a Baia da Guanabara nos idos de 1800, quando a esquadra foi recebida com uma salva de canhões e pelos fogos de artifício... Agora, o que ouvimos é a salva de tiro vindo em nossa direção dos morros que a circundam. Quem está de quatro, hoje, não é o domesticado e escravizado africano dos séculos passados, mas o ex-colonizador branco que tem que fazer de tudo para não quebrar diante da competição trazida pelos novos tempos da mundialização. Dói em meu peito saber que já não somos os preferidos, fomos preteridos por ingleses, franceses, americanos e, na atualidade, por coreanos e chineses, que alimentam os milhares de camelos nas ruas das capitais.

MENDES - É, caríssimo irmão, foi um erro ter levado de volta ao velho continente o Quinto Império, que com o passar dos anos foi para o quinto que o pariu! Seria melhor que por aqui tivessem ficado. Novos tempos seriam inaugurados e quem sabe, tivéssemos deixado de ser o gigante adormecido da letra do nosso hino nacional, para ser o Império da Nova Era. No entanto, só nos deixaram o despudor de não saber o que fomos e a dificuldade de definir o que somos. Então, a melhor coisa a fazer é se locupletar. Afinal, tanto lá como cá, estamos a se foder!

ISABEL $e$ LEOPOLDINA, encantadas uma com a outra.

ISABEL - Então, colega, como estão as cousas no velho continente?

LEOPOLDINA - Querida, uma concorrência braba. Agora que não temos mais fronteiras, não se sabe mais quem é de quem. E nós, como pobres da nova corte, estamos a nos foder mais que as outras. Sem falar da concorrência das "travecas" brasileiras, que nos colocam no chinelo com sua sensualidade tropical.

ISABEL - Brasileiras, é?

LEOPOLDINA - É...

ISABEL - Lá em Portugal? 
LEOPOLDINA - Pois.

ISABEL - Travecas?

LEOPOLDINA - Você não entende o que eu digo?

ISABEL - Aqui as cousas não são muito diferentes. O que se passa é que ainda preferem o produto importado. Ao produto nacional dão pouco valor. Só temos vez no Carnaval, quando os gringos para cá vêem. Mas como a oferta é sempre maior que a demanda, não ganhamos o suficiente e sempre estamos desvalorizadas.

LEOPOLDINA - O produto importado?

ISABEL - É preferido.

LEOPOLDINA - Gringos?

ISABEL - É.

LEOPOLDINA - Desvalorizadas, camarada!?

ISABEL - Você não entende o que eu digo? É uma infelicidade, mas que havemos de fazer?

LEOPOLDINA - Quando esse me contratou, fiz valer meus direitos de puta. Já está na hora de criarmos uma organização multinacional e estabelecermos reivindicações comuns e uma tabela de preços mínimos. Temos que recorrer a Organização Mundial do Trabalho e lutar para que se tirem os subsídios de nossas colegas americanas, francesas e polacas... e... ucrânias!

ISABEL - Você acha que eles vão nos ouvir? Nem podemos cogitar em fazer uma greve do sexo. A miséria mundial é tão grande que sempre haverá aquela disposta de tudo dar por um mísero prato de comida. É isso que nos torna frágeis. Antigamente isto era uma casa ilustre, onde vinha a fina flor! Agora... 
LEOPOLDINA - Antigamente... Se eu pudesse fazer o tempo voltar para trás...

ISABEL - Voltar para trás? Que nada! Eu queria era fazê-lo avançar! Chega! Não vamos desperdiçar esse encontro com mais choros e resmungos.

LEOPOLDINA - Sim, vamos rir na cara do destino, vamos beber, vamos cantar!

ISABEL - Somos putas, não somos? Então façamos uso da nossa profissão: o gozo.

(ISABEL $e$ LEOPOLDINA cantam "Epígrafe para a Arte de Furtar", poema de Jorge de Sena, música de Zeca Afonso:)

Roubam-me Deus

Outros o diabo

Quem cantarei

Roubam-me a Pátria

E a humanidade

Outros ma roubam

Quem cantarei

Sempre há quem roube

Quem eu deseje

E de mim mesmo

Todos me roubam

Quem cantarei

Quem cantarei

Roubam-me Deus

Outros o diabo

Quem cantarei

Roubam-me a Pátria

E a humanidade

Outros ma roubam 
Quem cantarei

Roubam-me a voz

Quando me calo

Ou o silêncio mesmo se falo

Aqui d'El Rey.

Todos brindam.

MENDES E RAFAELA - À primeira vez!

JUSSARA E TRANCOSO - Ao primeiro amor!

ISABEL E LEOPOLDINA - Ao primeiro beijo!

MENDES E RAFAELA - Ao primeiro boquete!

JUSSARA E TRANCOSO - Às relações América Latina - Europa!

ISABEL E LEOPOLDINA - Às relações Brasil - Portugal!

MENDES E RAFAELA - Às felações internacionais!

TODOS - Ao quinto dos impérios!

BENTO - (Saindo, enfurecido, do esconderijo.) E o que me roubam deixando de fora dessa festa internacional, ninguém está interessado!? Vocês acham que por causa de meia dúzia de europeus podem me deixar de fora dessa celebração da promiscuidade transnacional? Não se esqueçam, nativos, que a inquisição hoje em dia tem novas faces. Não pensem que porque os tempos são outros vocês ficarão impunes diante dos grandes senhores. Então, acho bom me conseguirem um convite, mesmo que de última hora, para participar desse embalo de mais de quinhentos anos. Não esqueçam que a roleta já foi inventada, à nossa geração só cabe aperfeiçoá-la!

MENDES - Bento! Eu disse para você esperar! 
BENTO - Você quer que eu lhe recorde o perdão da dívida que permite abrir esta espelunca todas as noites?

RAFAELA - Quem é esse? A cara não me é estranha...

ISABEL - Onde é que você se meteu, Bento?

LEOPOLDINA - Bento Teixeira, você está vivo!

BENTO - E bem vivo, agora que tenho nas mãos o mapa para o Eldorado! Todos estes anos à procura de uma pista, uma indicação nesta casa maldita, e agora de repente, estava bem à frente do meu nariz!

LEOPOLDINA - Com esse nariz não deve ter sido fácil, eu compreendo.

BENTO - Bem à minha frente, e agora é meu. Por isso, se querem chegar lá têm de contar comigo - e para já, em primeiro lugar, exijo um pedido de desculpas público por parte de todos!

TODOS - Desculpe!

BENTO - Enquanto vocês estavam conversando, entrei no túnel da Santa. Onde fui dar? A Eldorado! Não é um lago, não. É bem no meio do deserto... tal qual como Las Vegas! Tem que virar à esquerda, antes de entrar em Manaus, andar um pouco para sul, e bem no meio da Amazónia tem uma área desmatada a perder de vista, mais que suficiente para construir um país. Então eu entendi o meu sonho. Uma cidade na forma de casino. Quando ainda estava em Lisboa, a Santa disse-me num sonho para vir buscar um tesouro no bairro de Santa Cecília, bem perto do Minhocão. Nunca pude desconfiar que era aqui, na cave deste malafamado Galpão. Eu só vinha cá para me distrair com as meninas. Mas hoje eu vi. Vou ter um império! Vou ser imperador! Quem quiser que se junte a mim!

JUSSARA - Volte cá, seu Trancoso, estava ficando tão bom! 
Trancoso - Bento Teixeira, eu o intimo a fornecer esse mapa imediatamente!

BENTO - Todos esses anos... Nunca! Você sabe com quem está falando? Eu sou o único descendente vivo do imperador dos brasis, e pretendente legítimo ao trono de Portugal...

TRANCOSO - Ah sim, desde quando?

BENTO - (Chorando como uma criança.) Desde o desaparecimento de meu meio-irmão, a quem prestei votos de fidelidade, de quem fui afastado com o conluio da maldita Igreja e dos cruéis Republicanos, e cuja morte jurei vingar!

TRANCOSO - (Comovido.) Legítimo?

BENTO - Sim... e a quem duvidar, posso mostrar meu sinal de família!

JUSSARA - Não, não faça isso, Bento - tem crianças na assistência!!

TRANCOSO - Não precisa mais - eu reconheço sua honra. Pois cumpra seus votos agora, Bento Teixeira, meu irmão!

BENTO - (Ajoelhando-se.) El-Rey D. João!

TRAnCoso, aliás El-Rey - Sim, eu mesmo. Ouçam todos - nós estamos aqui para dar início ao último império, terminando essas repúblicas decandentes que foderam Portugal e o Brasil, e fazer do Eldorado marca registrada para os turistas estrangeiros.

MENDES - Bento não é judeu?

RAFAELA - Este não é o Abade de Trancoso?

MENDES - Ninguém aqui é o que parece ser?

RAFAELA - Então onde está o Abade? 
EL-REY - Não faça tantas questões a El-Rey, miserável utopista! (Pausa.) Nós o nomeamos nosso aio e valido, para que se cale um pouco. Você cansa os reais ouvidos com tanta conversa fiada. Agora, calado! E é se quer ganhar um título quando nós o dispensarmos. Bento, você será nosso guia.

BENTO - Finalmente serei Regente!

EL-REY - Isso veremos depois. Isabel, agora marquesa do Douro e de Copacabana, tratará do catering. Mendes, você fica responsável por registar todos os nossos passos. Será nosso cronista-mor, e Barão de Tocantins e Matosinhos. Leopoldina, condessa dos Algarves, do GrãoPará, do Paraná e do Ceará, cuidará das finanças. Precisamos de um ministro da guerra... Mas nós encontramos alguém no caminho. Jussara, por favor, descubra essa gazua e vá ter connosco ao quarto. Você será Duquesa de... depois logo se vê. As meninas farão parte do nosso real gabinete de leitura. Levaremos essa cultura secular para circular por esse imenso país. Vamos seguir a pista da Santa! Para a cave!

TODOS Não é p'ra quem quer,

É para quem pode.

Quem pode, manda.

Quem manda, fode.

Se El-Rey quer...

El-Rey pode.

Fode quem quer? Não!

Fode quem manda.

Homem, mulher,

Fode quaisquer.

Aqui d' El Rei!

Salve-se quem puder!

EL-REY - Esperem! Precisamos também de súbditos, para alimentar a tropa macaca do nosso exército de croupiers, porteiros, empregada, segurança, 
flanelinha, arrumador. Para todos... passaportes portugueses! (Distribui passaportes por todos.) Europeus! (Um passaporte que cai no público é resgatado na marra.) Partimos dentro de momentos! Vamos acordar as células monarquistas adormecidas!! Para o lago de Eldorado, a fundar a capital deste novo Estado!!

MENDes - (Para o público.) Bento pensa que encontrou o caminho para Eldorado na cave e que será regente de um novo império... Mas o verdadeiro Eldorado está na fonte de águas mágicas que corre aqui por baixo... numa curva, faz um espelho de água onde se reflecte a história. Quem se mirar nessas águas verá seu pai, seus egrégios avôs, todo o seu passado em perspectiva, na linha do tempo, e ficará com a terrível liberdade e responsabilidade de mudar o futuro. Naturalmente, toda a gente que encara seu verdadeiro rosto, enlouquece de tanto rir e chorar ao mesmo tempo. Isso eu descobri faz tempo. Foi o que aconteceu aos primeiros colonos que chegaram ao Novo Mundo, e essa loucura se disseminou por portugueses e brasileiros. Mas logo trataram de ocultar a terrível verdade, e o facto se tornou notícia, a notícia reportagem, daí documentário... depois reconstituição verídica... em pouco tempo já era a lenda da imagem da Santa encontrada num fio de água por baixo do Minhocão. Tanta força tem a lenda que chegou no sonho de Bento. Mas aqui, no cabaré, entre um número de variedades e um passo de dança, cada um é o que é. Toda a gente tem de encarar o futuro. Por isso reabri o cabaré, onde se põem e tiram as máscaras, e por segundos, cada um tem o vislumbre de quem é! Na casa da Mariquinhas, para cá das tabuinhas, essas raças vão todas se tornar mestiças, dos genes à propriedade individual. Ou não me chamasse eu Francisco da Costa...

ISABEL - (Da cave.) Mendes, vamos embora!

MENDES - Já vou! Eu também sonhei com Santa, e por isso vim para aqui. Será que sonhei errado? Mas porque terá ela enviado Bento? Que mapa ele encontrou? Quem vai sobreviver à maldição das águas mágicas? E quais as reais intenções de Trancoso, quero dizer El Rey, ao dizer com todas as letras: "Vou fazer de Eldorado uma marca registrada para os turistas estrangeiros»? E porque El Rey necessitou viajar clandestino, disfarçado de mim, na excursão de Rafaela? Terá ele enganado a Santa? Tantas perguntas 
sem resposta!... Cansei! Para poupar-lhes tempo e evitar longuíssimas divagações vou dar um salto e lhes mostrar, nas águas claras da imaginação, qual o resultado da grande expedição de Trancoso, quer dizer de El Rey, no afã de transformar Eldorado em uma marca registrada para os turistas estrangeiros. Uma ressalva, senhores. No início desse encontro lhes foi dito que seria realizado um concurso para eleger e sortear a felizarda da garçonnière. Esqueçam. Por interferência direta de El Rey a escolha foi já feita, por ele, em sua cama, sem maiores explicações. A bela Jussara que eu tanto estimava... (Começa a chorar.) O meu projecto de promover o turismo sexo-cultural foi usurpado pelo pretendente ao trono, e o meu produto principal destinado a um único consumidor...

ISABEL - (Da cave.) Mendes!

MENDES - Vou deixar eles fundarem esse grande bingo nacional e tentar a minha sorte. Esperem por mim!

No Eldorado.

\section{CENA III}

TRANCOSO Sou nada menos do que um rei,

sou nada menos que um monarca,

e não receio a escura Parca.

Sei dirigir a traquitana,

governar sei o meu país.

Não sou nenhum banana.

Se o sou, porém, ninguém mo diz.

Às ordens tenho várias tropas,

meus exércitos não são maus!

(Aponta as meninas.)

Eu sou aqui um rei de copas,

eu sou também um rei de paus!

Estamos aqui para instaurar esse novo Bingo Nacional. Agora de acordo com a modernidade das grandes transnacionais. Esse país atravessa uma grave crise moral, espiritual e intelectual... Deus não criou os homens iguais, uns têm mais qualidades que outros... Um regime igualitário como o nosso viola essa desigualdade entre os homens e nivela tudo por baixo. 
De Paris a Nova Iorque temos que desequalizar! E pra isso não há melhor que os jogos de sorte e azar!!

JUSSARA A Jogatina vai se instalar Por isso contente estamos A vida levamos assim Que o mundo alegre é para nós. Que importa que a moral, Não sei porque me queira mal?

Hei de cantar e rir,

Não hei de nunca me afligir

Leviana posso ser, talvez, porém

Filósofa também.

Quem se prostrar

No nosso altar

Será rico e se dará bem!

CORO É descarada a tal menina

Lições não há quem mais lhe dê!

O bingo as casas ilumina

Mas sempre cobra

O que lhes sobra...

EL-REY - Quem são essas personagens que fazem a fama do novo Bingo Nacional!?

RAFAELA “Este é a famosa Víspora

Já foi bem recebido

Dentro do lar doméstico

Com toda a distinção...

CORO Mas, afinal, o pícaro

Deu em andar metido

Por espeluncas sórdidas 
Que reprovadas são.

RAFAELA A loteria,

Velho jogo vagabundo,

Que foi em Roma o regalo

De Nero e de Heliogábalo,

E que hoje em dia

Ditosa vive

Em toda a parte do mundo,

A nova Austrália inclusive!

CORO Eis a rifa, joguinho matreiro

Oriundo dos tempos antigos

Conhecido no Rio de Janeiro

Pelo nome de ação entre amigos

RAFAELA Agora vou mostrar-vos um jogo

Muito respeitado,

É o câmbio!

Este bandalho

CORO - Que desce, desce, desce, e desce

E mais

E faz com que alguns ganhem sem trabalho

E muitos percam grandes capitais. ${ }^{1}$

EL-REY - Aqui vamos fixar nosso Sexto Império. O clima nos é favorável, temos muitas relações e somos considerados. Não faltarão elementos para exercer o poder absoluto. Não podemos escolher nada melhor. Não há terra onde teríamos tantos seguidores. Aqui o jogo é febre, moda, delírio! Tudo é pretexto para se apostar. Obras numa igreja? Loterias! Asilos de caridade? Loterias! Montepio? Loterias! Teatro? Loterias!

CORO - Todas as províncias jogam. Do sul ao norte, loterias e mais loterias.

EL-REY - Decididamente é um povo que nos convém! Em alguma parte,

${ }^{1}$ Parodiando Artur Azevedo, “O Bilontra”, Ed. FUNARTE, RJ. 1985, p. 493-494. 
pode isto dar certo, senão numa sociedade que se esfacela? E para melhorar teremos nossos representantes em terras de além mar, onde fixarão as matrizes para fugirem dos perigos que se tem em terras de ninguém. Isso é o que mais nos convém. Manter o pé em duas barcas, sem se ater a ninguém. E em nossas mulheres, taças milagrosas, fecundaremos uma nova raça, que fará jus as novas conquistas...

Serei nada menos que um rei

Serei nada menos que um monarca

Eu sou aqui um rei de copas,

E sou também um rei de paus! $!^{2}$

LEOPOLDINA - D. João, não voltaremos para Portugal? Vamos viver nesta terra de negros, onde a civilização não passa de uma promessa?

EL-REY - Leopoldina... parece não haver entendido o objetivo de nossa viagem. Com a nossa vinda um novo tempo se inaugura. Eldorado finalmente foi descoberto e as oportunidades se multiplicam.

LEOPOLD. E o que será de mim nessa terra?

Como suportarei esse calor tropical, essa lascívia nacional?

JUSSARA Se está tão descontente volte para o velho continente.

BENTO E o que me reserva esse novo Império? Não esqueçam fui eu que lhes mostrei o mapa de Eldorado.

EL-REY Ah! Querido Bento, poderá ser um corretor, um inspetor, ter um cargo promissor na nova burocracia, escolha o que melhor lhe aprouver...

BENTO Espere aí, mano! Desculpe: El-Rey... Creio que está a ignorar a minha pessoa...

2 Parodiando Artur Azevedo, “O Bilontra”, Ed. FUNARTE, 1985, p. 489. 
Pergunto o que serei

e vossa alteza me oferece um emprego?

LEOPOLD. E o que dizer do que está a fazer com a minha...

O que será de mim? Como sobreviverei?

Fui trocada por uma nativa sem eira nem beira...

JUSSARA Olha aqui, mademoiselle, se achas que és tão superior porque não voltas e não encontras outro impostor?

E você, Bento, poderá gerenciar meu novo negócio, agora internacionalizado, para melhor atender a nova clientela.

BENTO Não entendo o que quer dizer, à minha pessoa só cabe ser um modesto gerente?

Estão a subestimar a nossa gente.

No mínimo, ser regente!

EL-REY Melhor ser um gerente do que se tornar um indigente...

MENDES - (Entrando.) Ei! O que está acontecendo? Porque todo mundo está falando em verso e rimado? Não se esqueçam, estamos participando de uma revista, não de um drama ou de um teatro de agitação.

EL-REY - Mas justamente! No teatro de revista rima-se assim!

MENDES - Não é fantasia lá muito verosímil!...

EL-REY - Ouça lá... para verosimilhança não basta nós estarmos falando português do Brasil e de Portugal misturado? 
MENDES - Sim, mas...

BENTO Então, camarada, bola pra frente!

Não há-de ser nada.

Não esquente.

Tem outro problema

Mais premente.

$\mathrm{Eu}-$

EL-REY Meu querido anfitrião

Os vários gêneros teatrais,

O dramalhão de capa e espada,

A peça fina, e todos mais,

Estão aqui, promiscuamente,

Na nova torre de babel,

A nova farsa mais recente

E a velha farsa de cordel. ${ }^{3}$

MENDES - Mas sou eu ainda quem dirige os shows.

EL-REy - Mendes, Mendes... não te deixes levar pelo que já foste neste momento do que ainda serás... Pense nos casinos Eldorado...

MENDES - E você, Jussara, também está neste festim? Você que sempre amei?

JUSSARA - Mendes, Mendes... como artista, você nunca teve senso prático.

MENDES - Como assim senso prático? Quem organizou essa recepção? Quem teve a idéia dessa grande encenação?

EL-REY - Senhores, senhoras, olhem a compostura. Não vamos demonstrar nossos baixos instintos em público. Nos grandes empreendimentos há lugar para todos. A iniciativa nacional associada às transnacionais podem se constituir em poderosos instrumentos de modernização e incorporação das forças nativas...

\footnotetext{
${ }^{3}$ Parodiando Artur Azevedo, “O Bilontra”, Ed. FUNARTE, 1985, p. 528.
} 
RAFAELA - Falando nisso, senhor Mendes, podemos criar uma nova trading, uma joint-venture associada. Capital misto, empreendimento internacional de captação de recursos, usando os benefícios concedidos às ONGs de ajuda aos povos emergentes. Traduzindo, criar um jeito de nos locupletarmos nesta nova realidade.

MENDES - Você está propondo que nos transformemos em cafetões do Capital? Será isso o que resta ao nativo nacional? Onde está Isabel?

EL-REY - Precisamente. Isabel não volta mais... Estávamos à sua espera, Mendes, para um minuto de silêncio. Em breve inauguraremos um busto em homenagem à primeira mártir desta campanha. E o nosso primeiro bordel se chamará Casa da Mariquinhas, em homenagem à grande madame que foi. O guia Bento poderá explicar o que aconteceu.

MENDES - Bento, o que foi que aconteceu?

BENTO - Eu e ela íamos à frente para desbravar o caminho, mas ela voltou atrás para pegar uma garrafa de pinga... e nunca mais foi vista. Eu pensava que Isabel estava com eles, e eles pensavam que ela estava comigo. Só quando eles chegaram aqui percebemos que ela tinha desaparecido.

MENDES - Isabel!...

BENTO - Mas isso não interessa nada! Senhoras e senhores, eu quero deixar claro que a partir dessa cena passo a ser um opositor aberto ao Sexto Império. Meu sonho de Eldorado era de um novo perfil de nação, não esse bordel, e nem esse casino. Não foi para isto que Isabel morreu. E retomo minha condição de Judeu.

LEOPOLDINA - Muito bem!

BENTO - Lá se vão os anos em que éramos colônia de Portugal.

LEOPOLDINA - Isso mesmo! 
EL-REY - Mas você não veio para cá como colonizador? Agora está se queixando de quê?

BENTO - Não importa. Eu me solidarizo com quem colonizei! Agora que conhecemos o sabor da liberdade, não aceitaremos mais essa vergonha internacional. Viva Isabel!

LEOPOLDINA - Apoiado!

BENTO - Aliás, nós deveríamos declarar de novo a independência, a independência de Eldorado!

EL-ReY - Menos, Bento Teixeira, bem menos! Afinal, o que está aqui em negociação é apenas quem manda no show. É melhor esquecer esse item que você chama de vergonha nacional. No nosso show há espaço para todas as manifestações, sejam elas de onde forem. No que nos pode ajudar a independência se tudo se resume a rentabilidade? E aqui eu já disse: não se fala em política!!

BENTO - Então, vou para a clandestinidade. Adieu! (Canta "Minha Tribo Sou Eu", de Zeca Baleiro.)

Eu não sou cristão

Eu não sou ateu

Não sou japa não sou chicano

Não sou europeu

Eu não sou negão

Eu não sou judeu

Não sou do samba nem sou do rock

Minha tribo sou eu

Eu não sou playboy

Eu não sou plebeu

Não sou hippie hype skinhead

Nazi farizeu

A terra se move

Falou Galileu

Não sou maluco nem sou careta 
Minha tribo sou eu

Ai ai ai ai ai

Iê iê iê iê iê

Pobre de quem não é cacique

Nem nunca vai ser pajé

MENDES - Esperem, Isabel vem vindo!

(ISABEL, surge debaixo de um foco, cantando "Vou dar de beber à dor", de Amália Rodrigues.)

ISABEL Foi no domingo passado que passei

À casa onde viveu a Mariquinhas

Mas está tudo tão mudado

Que não vi em nenhum lado

As tais janelas que tinham tabuinhas

Do rés-do-chão ao telhado

Não vi nada nada nada

Que pudesse recordar-me as Mariquinhas

E há um vidro quebrado e isolado

Onde havia as tabuinhas

EL-REY - Isabel, mas que surpresa!

LEOPOLDINA - Que surpresa, não, que milagre!

RAFAELA - Não posso crer que tenha sobrevivido a tamanha queda e a correnteza das águas.

JUSSARA - Todos pensámos que estava morta.

ISABEL Entrei e onde era a sala agora está

À secretária um sujeito que é lingrinhas

E não há colchas com barra

Nem viola nem guitarra

Nem espreitadelas furtivas das vizinhas 
O tempo cravou a garra

$\mathrm{Na}$ alma daquela casa

Onde às vezes petiscávamos sardinhas

Quando em noites de guitarra e de farra

Estava alegre a Mariquinhas.

MENDES - (Ao público diretamente.) Como cronista desta caravana, relato ao público presente que esta passagem do desgarramento de Isabel e o seu quase falecimento nas águas do Amazonas, não foi por vós assistida por questões técnicas de nossa produção, e por questões artísticas de nossos dramaturgos. No entanto, o fato se deu, e por isso estão vendo tanta perplexidade, por parte dos personagens, pela volta da minha antiga sócia. Ainda por cima cantado como forma de expressão, uns versos novos... Ah, mas que alívio ela estar viva, foi um luto tão sofrido!

ISABEL As janelas tão garridas que ficavam

Com cortinados de chita às pintinhas

Perderam de todo a graça

Porque é hoje uma vidraça

Com cercadura de lata às voltinhas

E lá para dentro quem passa

Hoje é para ir aos penhores

Entregar ao usuário umas coisinhas

Chegou a esta desgraça toda a graça

Da casa da Mariquinhas.

Para terem feito da casa o que fizeram

Melhor fora que a mandassem paras alminhas

Pois ser casa de penhor

$\mathrm{O}$ que foi viveiro de amor

É idéia que não cabe cá nas minhas

Recordações de calor

E das saudades o gosto

Que vou procurar esquecer numas ginjinhas

Pois dar de beber à dor é o melhor

Já dizia a Mariquinhas. 
MENDES - (Para Isabel.) Isabel, que bom que voltou! Na sua ausência sentime traído, apunhalado pelas costas...

BENTO - Menos, Mendes, menos... Afinal, você só pensou em livrar o fundo das suas costas... O fato, Isabel é que a patuléia nacional mais uma vez se vendeu e foi passada para trás. Mas quero dizer que tens um mim um aliado e um guerreiro pronto para combater as injustiças...

ISABEL - Menos, Bento, menos... Afinal, se é um aliado tão pronto a me defender porque não pulou no rio para me salvar? Mas julgo que me fizeram um bem ao deixar com que boiasse rio abaixo. Encontrei-me com meu ser interior mais profundo e, graças às lendárias Amazonas, fui salva. Reencontrei o motivo da minha vida. Sinto-me uma verdadeira herdeira das grandes mulheres libertadoras desse continente latino que me sucederam e pereceram na luta para castrar o falo do poder patriarcal que nos emporcalha há anos. Voltei para redimir as mulheres exploradas de todo o mundo. Voltei pra refundar o Cabaré da Santa e restaurar os nossos direitos... Afinal, a mulher é a única verdade histórica, e seu ventre é uma taça milagrosa!

EL-REY - Você está passando bem, Isabel?

RAFAELA - Ela deve estar com insolação...

JUSSARA - Deve ser o efeito do tacacá amazonense!

BENTO - Está sobre o feitiço das águas da fonte de Eldorado. É um estado passageiro. Quem sempre foi cortesã não vira, de uma hora para outra, uma extremista revolucionária...

JUSSARA - Ela já tinha estes laivos de má consciência sempre que bebia. E viram que ela entrou a cantar Vou dar de beber à dor...

ISABEL - Nada disso, curei a minha dependência do álcool.

MENDES - Como? 
JUSSARA - É mesmo?

ISABEL - Fiz todos os passos das AAA.

MENDES - Das quê?

ISABEL - As Alcoólicas Anónimas da Amazónia. Estou curada e não só deixei de ver a dobrar como vejo tudo mais nítido.

RAFAELA - Como conselheira, aconselho a que ofereça à formosa dama algum cargo ou encomenda que demonstre o seu reconhecimento pelos anos de serviço prestado...

LEOPOLDINA - Faça de mim segundo sua vontade. Como um Dom Sebastião, de saias, você retornou para restaurar a dignidade de nós mulheres. Agora pode ser fundado o Sexto Império, sob a nossa égide... O Brasil será das mulheres!

MENDES - O camarada Marx pode ter errado em muita coisa, mas numa ele foi mestre, fez um gol de placa - a ligação que fez entre a economia e a história. Parece uma piada grotesca o fato dos jesuítas, que aqui aportaram, terem traduzido os Dez mandamentos para o Tupi. Soa a uma bufonaria de mau gosto a insistência de querer incutir no índio nu, polígamo e ocioso o respeito à mulher do próximo e a guarda do domingo para o descanso. Como você, D. João, instituíram na selva matriarcal o trabalho escravo, a divisão da sociedade em classes. Essa é a sua hybris, Trancoso...

JUSSARA - Mendes, que é isso, você está recebendo algum santo? Que carrego bravo, colega! Sai pra lá, encosto...

Mendes desmaia.

ISABEL - Estou tomando posse de minhas propriedades. Estou reinaugurando o Cabaré da Liberdade dentro de novos padrões. Aqui vigorará a democracia, sem liberalidade. Instituo algumas regras básicas e uma delas é que, a partir de hoje, volto a assumir as minhas obrigações de guardiã das Meninas e do nosso secular ofício. Liberto-as do julgo dos 
perversos e entrego-lhes o livre-arbítrio de decidirem por si o que dão, a quem dão e por quanto dão... O livre comércio se faz necessário nestes tempos de internacionalização...

LEOPOLDINA - Não sabes o bem que estás a fazer, com tuas decisões, a esse corpinho tão castigado, nos últimos tempos!

JUSSARA - El-Rey, o que será de mim? O que será de nós?

EL-REY - Orgulhosamente sós, continuaremos. Vamos candidatar-nos a um lugar no parlamento.

ISABEL - Eu lamento, caros espectadores, que tenham vindo aqui ao engano, para assistir ao show de cabaré anunciado pelo Mendes mas, vendo bem as coisas, descobrimos uma coisa melhor quando já estávamos a meio do caminho. Pois que acabe a missão Eldorado para eles, mas não sem antes percebermos que o Eldorado está aqui. Nós somos o Eldorado, ele não está noutro lugar. Até porque está mesmo na cave. Se nós dobrarmos o tempo ao meio, que data se vai alinhar com a origem dos tempos? Não sei como vamos financiar isto sem o dinheiro das comemorações luso-brasileiras, mas também porra, é hora de parar de comemorar e passar a fazer algo que outros possam comemorar daqui a cem, duzentos, ou quinhentos anos.

MeNDes - (Acordando.) Bem-vindos ao Cabaré da Liberdade! Hoje assistirão...

ISABEL - (Interrompendo.) Mendes! Hoje não vamos mais contar a história ou estória de ninguém. Vamos fazer a nossa história.

MENDES - Como assim?

ISABEL - Metendo mãos à obra. Vamos tomar posse do país.

MENDES - Mas a fingir?

JUSSARA - A fingir que é a sério? 
ISABEL - Não, tomando posse a sério.

MENDES - Mas... como tomando posse? Não se pode, eu não posso, pegar no país e pô-lo debaixo do braço.

ISABEL - Mas não é disso que se trata... Tomamos posse aqui e agora da nossa parte, da nossa responsabilidade. Toda a gente tem um documento de identidade? Pode ser cartão de sócio de clube de futebol, vale na mesma, porque isto anda tudo ligado. Peguem nele, ou ponham a mão nele. Como se fosse a vossa bandeira pessoal, que é, mas também é o emblema da aldeia. Então é só jurar sobre ele. Este país é meu, eu sou deste país... quem diz país diz casa, diz cidade. Se isto é meu e eu sou disto, tenho de cuidar dele. Se eu tivesse o eldorado ou a galinha dos ovos de ouro, não ia matála para fazer arroz de cabidela, ou ia? E não vale a pena adiar, temos de tomar posse o mais rápido possível e por as coisas a acontecer. Vamos beber! Meninas: tenho versos novos, para a reinauguração do Cabaré!

ISABEL - ("A Casa da Mariquinhas", de Alfredo Marceneiro)

É numa rua bizarra

A casa da Mariquinhas

Tem na sala uma guitarra

E janelas com tabuinhas

Vive com muitas amigas

Aquela de quem vos falo

E não há maior regalo

Que a vida de raparigas

É doida pelas cantigas

Como no campo a cigarra

Canta o fado à guitarra

De comovida até chora

A casa alegre onde mora

É numa rua bizarra

Para se tornar notada

Usa coisas esquisitas

Muitas rendas, muitas fitas 
Lenços de cor variada.

Pretendida, desejada

Altiva como as rainhas

Ri das muitas, coitadinhas

Que a censurem rudemente

Por verem cheia de gente

A casa da Mariquinhas

É de aparência singela

Mas muito mal mobilada

E no fundo não vale nada

O tudo da casa dela

No vão de cada janela

Sobre coluna, uma jarra

Colchas de chita com barra

Quadros de gosto magano

Em vez de ter um piano

Tem na sala uma guitarra.

Um cofre-forte comprou

E como o gás acabou

Ilumina-se a petróleo.

Limpa as mobílias com óleo

De amêndoas doces e mesquinhas

Passam defronte as vizinhas

Pra ver o que lá se passa

Mas ela tem por pirraça

Janelas com tabuinhas.

É numa rua bizarra

A casa da Mariquinhas

Tem na sala uma guitarra

E janelas com tabuinhas

MENDES - Aqui me despeço. Nada mais temos em comum. Vou continuar meu caminho rumo ao show biz da América do Norte, cansei do realismo do terceiro mundo. Prefiro a espetacularidade do norte! (Canta "Fiz Leilão 
de Mim".)

Talvez de razão perdida

Quis fazer leilão da vida

Disse ao leiloeiro

Venda ao desbarato

Venda o lote inteiro

Que ando de mim farto

Meus versos que não são versos

Atirei ao chão dispersos

A ver se algum dia

O mundo pateta

Por analogia

Diz que sou poeta

Refrão:

Fiz leilão de mim

E fui por fim apregoado

Mas de mau que sou

Ninguém gritou arrematado

Fiz leilão de mim

Tinhas razão minha almofada

Com lances a esmo

Provei a mim mesmo

Que não valho mais que nada

Também quis vender meu fado

Meu modo de ser errado

Leiloei ternura

Chamaram-me louco

Mostrei amargura

E o mundo fez pouco

Depois leiloei carinho

E em praça fiquei sozinho

Diz-me a pouca sorte

Que para castigo

Até vir a morte

Vou ficar comigo. 
ISABEL - Mendes, Mendes, não se iluda, a nós, personagens perdidos dessa história, sempre caberá a parte podre da fruta. Mas não se esqueça, aqui ainda podemos ser...

IsABEL - (Canta "Novos Rumos" de Rocinha e Orlando Porto.)

Vou imprimir novos rumos

Ao barco agitado

Que foi minha vida

Fiz minhas velas ao mar

Disse adeus sem chorar

E estou de partida

Todos os anos vividos

São portos perdidos

Que eu deixo pra trás

Quero viver diferente

Que a sorte da gente

É a gente que faz. ${ }^{4}$

Entra a SANTA.

SANTA - Então é aqui o antigo Cabaré da Santa?

RAFAELA - Agora sim, é a Morte...

ISABEL - O novo Cabaré, sob nova direcção. O que deseja?

SANTA - Procuro por um homem de nome Trancoso. Conhecem?

Todos se calam.

SANTA - Há uma mensagem para ele, mas só posso entregá-la pessoalmente.

EL-REY - Aqui está quem procuras! Do que se trata!?

\footnotetext{
${ }^{4}$ Esta música está gravada por Paulinho da Viola, no CD «Paulinho da Viola».
} 
MENDES - Nada disso, o verdadeiro Trancoso sou eu!

RAFAELA - Pai!

MENDES - Filha!

RAFAELA - Por isso resistias aos meus avanços.

MENDES - Sim, filha, isto não é tragédia grega, não tem espaço para incestos.

RAFAELA - Mas porque não davas para Isabel?

MENDES - Para preservar a minha identidade. Quando ela visse meu bacamarte... não me ia deixar descansar. Dizem que tenho pau doce...

RAFAELA - Ai, pai!

JUSSARA - Se era doce, amargou!

MENDES - E para me ocultar de todos os meus filhos e filhas. Já pensou se todos viessem reclamar sustento?...

SANTA - Tive de mandar alguém com o teu nome para te fazer sair da toca! (Para Mendes.) Preciso que retorne a Portugal, para repovoar aquela nação. Estamos precisando de pau, e nada melhor que pau-Brasil. Mas agora tem de parar mesmo: já tem brasileiro a mais. De volta para Portugal!

ISABEL - Mas ele não consegue mais pôr-se em pé!

SANTA - Isso é verdade?

MENDES - Eu... (Pausa.) É!

SANTA - Essa raça de portugueses está degenerada! Todos me enganaram. Francisco da Costa, que eu trouxe para fundar São Paulo, se escondeu num cabaré, sonhando em descobrir a identidade... Bento Teixeira, enviado 
logo que perdi a pista desse safado, seguiu outros cursos: agiotagem e lenocínio de luva branca. E ainda leu o mapa ao contrário! Imbecil... Rafaela, filha do marinheiro português da ilha de Utopia, não passa de uma oportunista... E tu, D. João, querias aprontar um império do jogo! Os teus planos de casino iriam por água abaixo, mesmo. A fonte de liquidez que procuravas, a lavagem de dinheiro, o estelionato, a corrupção, já está tomada no Brasil... Estes mesmos terrenos em que pensavam fundar o império já têm proprietários. E talvez sejam de tua família, mas duvido que te reconheçam. Agora entendo, tinham todos uma grande falta de carácter! Só Isabel compreendeu o caminho. Por isso, o Brasil, a partir de agora, será feminino! Terras de Vera Cruz. Mariquinhas, eu te nomeio a cabaretière deste lugar, e Santa no lugar da Santa.

ISABEL - Eu? Mas... Quem será nossa padroeira?

SANTA - Madroeira, a partir de agora, madroeira! Tu mesma. A Santa Mariquinhas!... E tu ficarás encarregue de expedir brasileiros para povoar Portugal. Vocês os quatro, dêem prova de vossos talentos e providenciem as viagens, os vistos, os empregos e, sobretudo, lugar onde eles se possam reproduzir, de preferência cruzando com os nativos. A ver se mestiçamos o sangue lusitano. Eu estou farta.

ISABEL - E tu?

SANTA - Eu vou finalmente poder partir em tournée com a nossa banda. (Pausa.) Faço parte de uma girlsband com as minhas primas Fátima, Nazaré, Aparecida e Copacabana. O grupo chama-se Todas-as-Santas. Vamos começar a Milagres tour pelos países da África lusófona. Temos o patrocínio da Fruit de la Passion.

CORO - Voulez coucher avec moi?... ce soir! (Saem.)

JUSSARA - É isso o pós-colonialismo...

BENTO - É, isso é, nós é que vamos colonizar Portugal!

JUSSARA - Não disse?... 
LEOPOLDINA - Espere aí! Eu não quero colonizar ninguém. Muito menos a terra da minha mãezinha, que está lá em cima no céu, coitadinha, Deus a tenha em paz...

BENTO - Não? Você acha?... Bom, nesse caso... Foi só uma ideia...

RAFAELA - Não, ele está certo. Já pensou em tudo o que poderíamos levar para lá: show musical, artesanato, novela, concurso...

MENDES - A cultura do Brasil!

BENTO - Culto evangélico!

EL-REY - Futebolista!

MENDES - Actor, director, músico...

BENTO - Manicure, esteticista, garçom, balconista, prostituta, operário... Nisso as nossas marcas são fortes! Temos identidade de mercado!

RAFAELA - Podemos construir algo novo!

EL-REY - Portugal será baptizado Portuganhangabaú!

MENDES - Vocês só pensam em coisas materiais. Temos de levar a liberdade daqui, o jeito brasileiro de ser...

LeOPOLDINA - Mas... e a liberdade mesmo? Porque isso é só liberdade de costumes.

ISABEL - Mal a gente tenha, manda para lá.

BENTO - Avião, soja, carne, computador.

RAFAELA - É embarcar!

MENDES - Você fica, Isabel? 
ISABEL - Fico sim...

Aqui não tem terramoto

Aqui não tem revolução

É um país abençoado

Onde todo mundo põe a mão...

RAFAELA - Venha, Jussara! Não tenha medo!

Mendes Adeus, Brasil,

olá, Portugal!

EL-REY Feito por mim,

$O$ visto é legal.

MENDES (Só não tem visto

pra Roberto Leal!

Sua nefasta

carreira musical

tem destruído a

imagem nacional.

JUSSARA Adeus, Brasil,

olá, Portugal...

BENTO Sendo eu o guia

não vai se dar mal

RAFAELA Já está tratada a

questão laboral

MENDES Falta marcar

a hora do bacanal.

Todos Adeus, Brasil,

olá, Portugal! 
Partem em viagem.

À chegada:

LEOPOLD. Anjos da igreja de São Francisco

Dai vossas bênçãos aos meus filhinhos

que hão-de nascer tão perfeitinhos quanto vós, nossos ricos anjinhos, cujo sexo foi esculpido por índios, sem mais discussão dos bizantinos.

E semeai em nós os primeiros homens afro-luso-brasileiros.

ISABEL De Santos vejo agora Todo o vale do douro As vinhas, as latadas, São meu ancoradouro

Por Anhangabaú O lago de Eldorado Inunda por completo As salinas do Sado

JUSSARA Nas ruas de Lisboa

O jacarandá em flor

Recorda minha casa

Em São Salvador

Perco-me no Sertão

Em pleno Alentejo

Voando no dorso

De um touro bravo

MENDES Na montado, as palmeiras

Na lezíria, o cafezal

Pinga de cana nas pipas

Cachaça meridional 
EL-Rey Na Brasileira do Chiado,

A estátua de Pessoa

Pede um café ao empregado.

Será que estou num sonho?

E aguardente de medronho,

Lembra-se o bronzeado.

Só tem de cana, senhor,

Responde o empregado.

E a maneira como entoa,

A pronúncia que ressoa,

Tem que ser de Salvador.

RAFAELA Mais um emigrante baiano

que está bem emigrado.

Siga o nosso o plano

Como ficou combinado.

BENTO Na boutique pronto-a-vestir

Com sorriso que convence

Vende biquínis do Brasil

Uma garota cearense.

Namora um rapaz de Minas

Que trabalha na construção.

Querem ter três meninas

Dois rapazes e um cão.

RAFAELA Nada de contraceptivos

orais, profiláticos ou mecânicos.

Devem ficar activos.

Não perder tempo com sexo tântrico.

EL-REY Este domingo à tardinha

Tem jogo de futebol

Vou lá contar quantos é que

em vez de golo gritam gol 
LEOPOLD. Eu irei à assembleia

Contar os «Jesus me ama»

Quando começar o Faustão

Por favor me chama.

RAFAELA Hoje tem show musical

Da Mercury e da Sangal

Na torre de Belém.

Você não vem?

LEOPOLD. Não quero perder a novela.

Aquela da favela.

RAFAELA Já são mais de cem!

Não há mais ninguém?

EL-REY A linda manicure,

A quem uma noite,

Num assomo de loucura

Roubei um boquete.

BENTO Fomos reencontrar

Num apê alugado

Com mais cinco garotas

A um preço bem barato

RAFAELA E você, Mendes, nada?

A Santa vai ficar danada.

MENDES Eu vi aqui bem perto

Na praça do Rossio

Dois brasileiros sem tecto.

E acabei a madrugada

Cantando pros mendigos

Uma velha toada: 
(«Fado Tropical», alterado:)

Oh, musa do meu fado, Oh, minha mãe gentil, Te deixo, consternado

No primeiro abril.

Mas não sê tão ingrata,

Não esquece quem te amou

E em tua densa mata

Se perdeu e se encontrou.

TODOS Ai, esta terra ainda vai rever o seu perfil, Ainda vai tornar-se uma parte do Brasil

Sabe, no fundo eu sou um sentimental. Todos nós herdamos no sangue

lusitano uma boa dose de lirismo. Além da sífilis, é claro. Mesmo quando as minhas mãos estão ocupadas em torturar, esganar, trucidar, meu coração fecha aos olhos e, sinceramente, chora.

Com avencas na caatinga,

Alecrins no canavial, Licores na moringa, Um vinho tropical.

E a linda mulata, Com rendas de Alentejo, De quem numa bravata, Arrebato um beijo.

TODOs Ai, esta terra ainda vai rever o seu perfil, Ainda vai tornar-se uma parte do Brasil.

Meu coração tem um sereno jeito 
E as minhas mãos o golpe duro e presto

De tal maneira que, depois de feito,

Desencontrado, eu mesmo me contesto.

Se trago as mãos distantes do meu peito,

É que há distância entre intenção e gesto.

E, se o meu coração nas mãos estreito,

Me assombra a súbita impressão de incesto.

Quando me encontro no calor da luta

Ostento a aguda empunhadura à proa,

Mas o meu peito se desabotoa.

E, se a sentença se anuncia, bruta,

Mais que depressa a mão cega executa

Pois que senão o coração perdoa.

Guitarras e sanfonas

Jasmins, coqueiros, fontes

Sardinhas, mandioca

Num suave azulejo.

E o rio Amazonas

Que corre Trás-os-Montes

E, numa pororoca,

Desagua no Tejo

TODOs Ai, esta terra ainda vai rever o seu perfil, Ainda vai tornar-se uma parte do Brasil.

Ai, esta terra ainda vai rever o seu perfil, Ainda vai constar no mapa do Brasil.

Ai, esta terra ainda vai rever o seu perfil, Ainda vai tornar-se... o vigésimo oitavo estado do Brasil! 
Recebido em 2 de novembro de 2020

Aprovado em 8 de dezembro de 2020

\section{Licença: (c) (i) ():}

\section{Reinaldo Maia}

Dramaturgo. Graduado em Filosofia pela Universidade de São Paulo. Fundador do grupo Folias D'Arte e fundador do Movimento Arte Contra a Barbárie. Falecido em 17 de abril de 2009. A publicação do texto foi gentilmente autorizada por sua viúva, Giselda Fernanda Pereira.

Jorge Louraço Figueira

Dramaturgo. Doutorando em Estudos Artísticos na Universidade de Coimbra com bolsa da FCT, dramaturgo residente do Teatrão (Coimbra, Portugal), docente da Escola Superior de Música e Artes do Espetáculo (Porto, Portugal) e crítico de teatro do jornal Público.

Contato: jorgelouraco@gmail.com

(D): https://orcid.org/0000-0002-7899-7555

Helderson Mariani Pires

Em artes, Helder Mariani. Doutor e mestre em Filosofia pela Pontifícia Universidade Católica de São Paulo (PUC-SP). Especialista em Psicodrama pelo Instituto Bauruense de Psicodrama (IBAP). Bacharel em Direito pela Universidade de Ribeirão Preto (UNAERP).

Contato: heldermariani@terra.com.br 